\title{
AUTOMATIC PROGRAMMER FOR AN ELECTRON BEAM WELDER
}
J. H. Burkhardt, Jr
C. M. Davenport
D. H. Gray

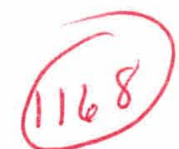

OAK RIDGE Y-12 PLANT OAK RIDGE. TENNESSEE 


\section{DISCLAIMER}

This report was prepared as an account of work sponsored by an agency of the United States Government. Neither the United States Government nor any agency Thereof, nor any of their employees, makes any warranty, express or implied, or assumes any legal liability or responsibility for the accuracy, completeness, or usefulness of any information, apparatus, product, or process disclosed, or represents that its use would not infringe privately owned rights. Reference herein to any specific commercial product, process, or service by trade name, trademark, manufacturer, or otherwise does not necessarily constitute or imply its endorsement, recommendation, or favoring by the United States Government or any agency thereof. The views and opinions of authors expressed herein do not necessarily state or reflect those of the United States Government or any agency thereof. 


\section{DISCLAIMER}

Portions of this document may be illegible in electronic image products. Images are produced from the best available original document. 
Reference to a company or product name does not imply approval or recommendation of the product by Union Carbide Corporation or the U.S. Atomic Energy Commission to the exclusion of others that may meet specifications.

Printed in the United States of America. Available from National Technical Information Service

U.S. Department of Commerce

5285 Port Royal Road, Springfield, Virginia 22151

Price: Printed Copy \$3.00; Microfiche $\$ 0.95$

This report was prepared as an account of work sponsored by the United States Government. Neither the United States nor the United States Atomic Energy Commission, nor any of their employees, nor any of their contractors, subcontractors, or their employees, makes any warranty, express or implied, or assumes any legal liability or responsibility for the accuracy, completeness or usefulness of any information, apparatus, product or process disclosed, or represents that its use would not infringe privately owned rights. 


\title{
AUTOMATIC PROGRAMMER FOR AN ELECTRON BEAM WELDER
}

\author{
J. H. Burkhardt, Jr \\ C. M. Davenport \\ D. H. Gray
}

Oak Ridge Y-12 Plant

P.O. Box Y, Oak Ridge, Tennessee 37830

Date Issued - March 14, 1973

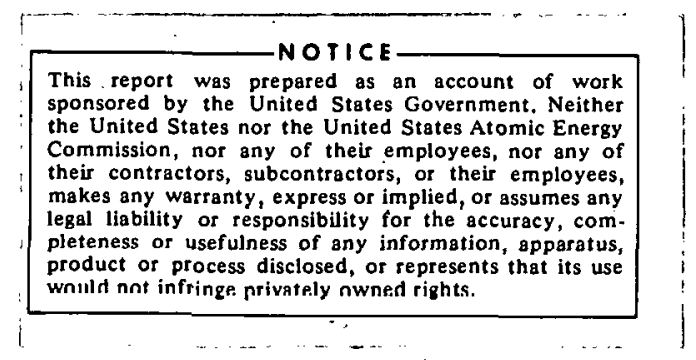

Prepared for the U.S. Atomic Energy Commission Under U.S. Government Contract W-7Anseng-3f 


\section{THIS PAGE}

\section{WAS INTENTIONALLY LEFT BLANK}




\section{ABSTRACT}

A medium-sized computer was interfaced to a 6-kw electron-beam welder to provide automatic programming of weld parameters for single and multipass welds. Changes in six parameters are synchronized to the position of the part being welded. 
CONTENTS

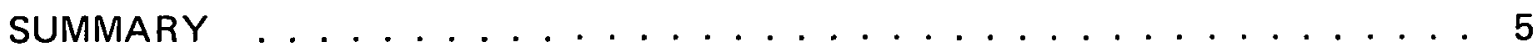

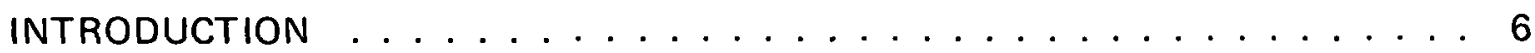

AUTOMATIC PROGRAMMER .................. 7

System Description . . . . . . . . . . . . . . . . . 7

Programmer Control Console . . . . . . . . . . . . . . 7

Computer Interface . . . . . . . . . . . . . . . . . 12

Computer Software . . . . . . . . . . . . . . . 12 


\section{SUMMARY}

A medium-sized computer was interfaced to a 6-kw Hamilton Standard electron-beam welder to provide automatic programming of weld parameters for single and multipass welds. The system programs focus current, high voltage, beam current enable, beam current value, beam current slope up/down, beam deflection enable, and data change point. The system software provides for storage of weld description files, editing of stored files, computer-assisted calibration and setup, and feedback of digital programming data during an automatic weld. 


\section{INTRODUCTION}

Certain electron-beam welding operations at the Oak Ridge $\mathrm{Y}-12$ Plant ${ }^{(a)}$ require several passes of the beam. The first pass is used to clean the joint surfaces; then one or more closure passes are made; and, finally, the joint is filled and dressed in subsequent passes. Each pass requires fixture positioning and adjustment of one or more machine control parameters. Previously, the machine was stopped after each pass and adjusted for the next. This procedure was tedious, and the delay between passes added to the welding time and affected weld consistency.

An investigation was conducted to determine if a commercial programmer could meet the multipass programming requirements for the 6-kw Hamilton Standard electron-beam welder used by the Welding Development Department. None of the commerical programentrers could meet Y-12's particular requirementș, so an automatic programmer was developed for this app̈lication. The programmer is being used to make multipass development welds much faster and with better weld consistency, compared to the manual control method.

(a) Operated by the Union Carbide Corporation's Nuclear Division for the US Atomic Energy Commission. 


\section{AUTOMATIC PROGRAMMER}

\section{SYSTEM DESCRIPTION}

The Hamilton Standard 6-kw electron-beam welder operates by accelerating a beam of electrons from a filament to the workpiece in a vacuum. The amount of electron current is determined by the filament current, the accelerating voltage difference between the anode and the workpiece, and by the grid bias control voltage. The focal point of the electron beam is raised or lowered by changing the current through a focusing coil. Beam deflection is implemented by exciting deflection coils. All welding parameters except the beam current are independent parameters; ie, they are not affected by other parameter settings.

Careful examination of the problem indicated that a computer-oriented system would be required to provide flexibility for welding development. The system, seen in Figure 1 , consists of a programmable control console (PCC) interfaced to a medium-sized computer. The PCC controls the machine parameters and is located with a Teletype at the welder (see Figure 2). The computer and interface, shown in Figure 3, are located in another building. The computer is employed on a multiuser basis to store the desired sequence of weld parameters and to send command data to the PCC at the proper time. Table 1 lists the programmed parameters and their range and tolerance when applicable.

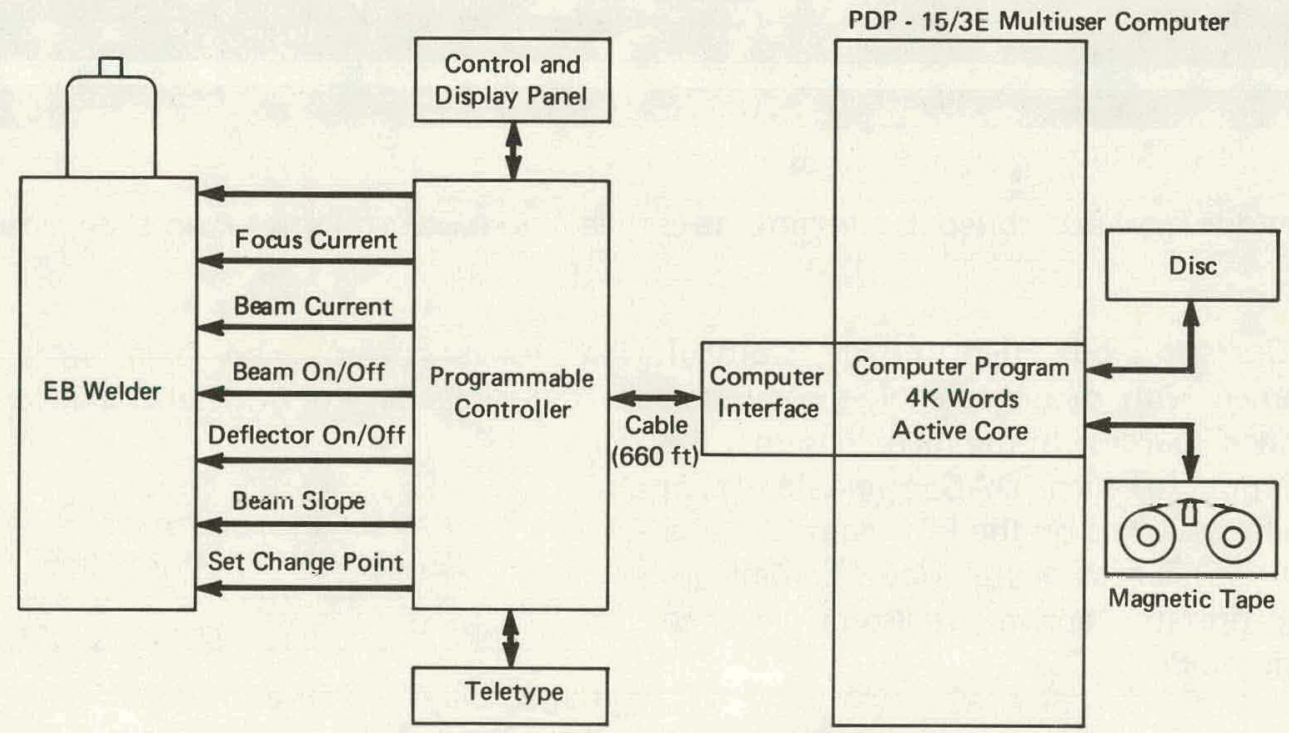

Figure 1. COMPUTER AND WELDER HARDWARE RELATIONSHIPS.

\section{Programmer Control Console}

A block diagram of the PCC is presented in Figure 4. The PCC provides for both manual, single-pass welding, and automatic single-pass and multipass welding. Data distribution logic directs new data from the computer to the appropriate buffer registers and then to active registers when needed in the automatic mode. 


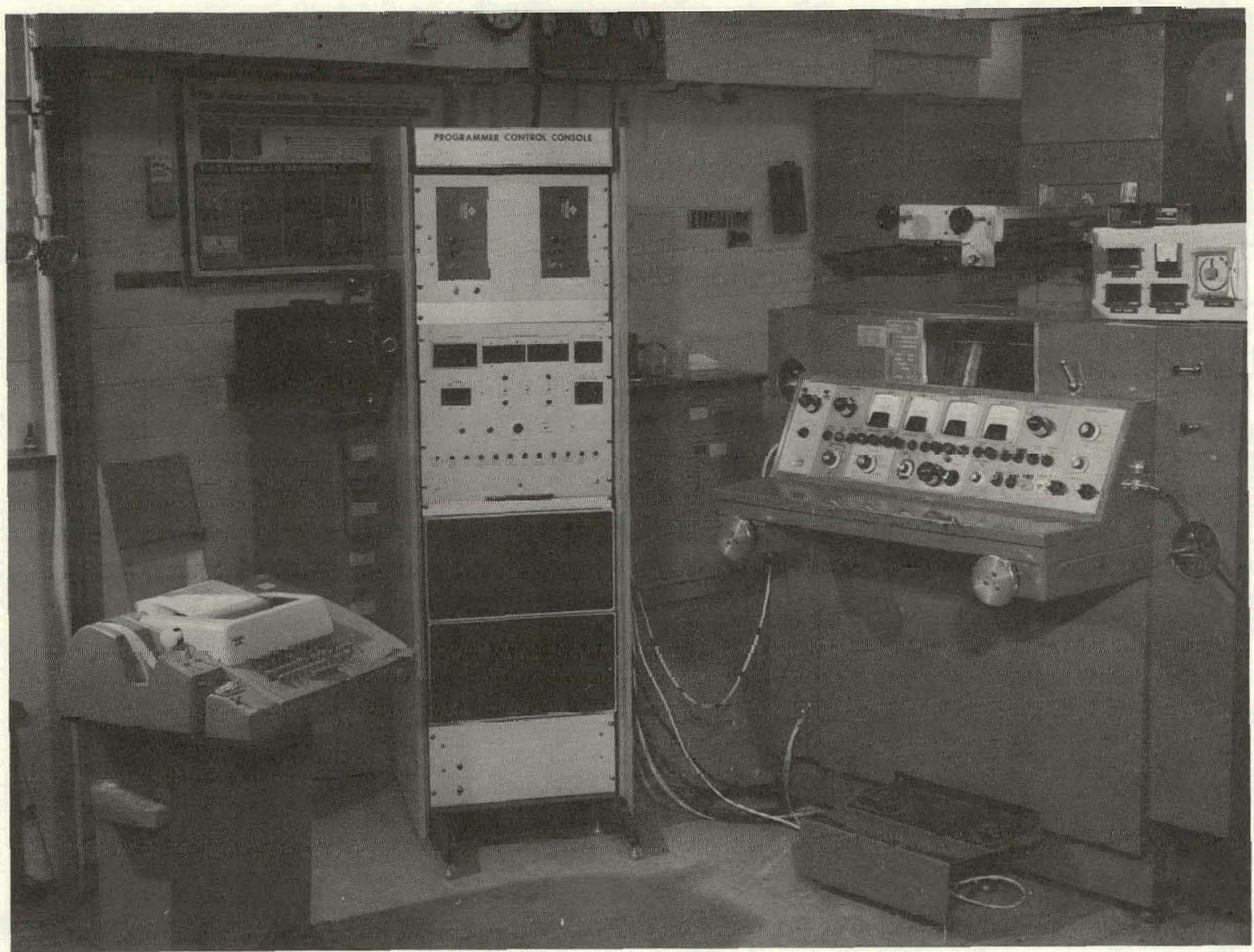

149658

Figure 2. PROGRAMMABLE CONSOLE CONTROL, TELETYPE, AND HAMILTON STANDARD ELECTRON BEAM WELDER.

Focus Current and High-Voltage Control-The focus current and high voltage are programmed with digital-to-analog converters (DAC) replacing the original potentiometers as reference sources. In the manual mode, the digital input to each DAC originates from lever-wheel switches on the PCC control panel (see Figure 5). These digital inputs come from the appropriate active registers in the automatic mode.

The focus current and high voltage are independent parameters. That is, their value depends only on the digital input to the appropriate DAC. Calibration tables are established by the operator in the manual mode by relating digital input to the parameter value. These data are transferred to the computer via Teletype and used to generate digital data for use in the automatic mode.

Table 1

RANGE AND TOLERANCE OF PROGRAMMED PARAMETERS

\begin{tabular}{ccc}
\hline Parameter(1) & Range & Tolerance \\
\hline Program Length & 1 61 Data Ects & \\
Focus Current & $0-1,100 \mathrm{~mA}$ & $+0,-1 \mathrm{~mA}$ \\
High Voltage & $0-150 \mathrm{kv}$ & $\pm 0.1 \mathrm{kv}$ \\
Beam Current & $0-40.00 \mathrm{~mA}$ & $\pm 0.5 \%$ \\
Beam Current & & \\
$\quad$ Rise and Fall & $1.0-20.0 \mathrm{~mA} / \mathrm{sec}$ & $\pm 5 \%$ \\
Beam On-Off & - & - \\
Deflection On-Off & - & - \\
Data Change Point & $0-9999$ Degrees & \pm 1 Degree
\end{tabular}

(1) Two auxiliary functions were supplied for future programming of such devices as a wire feeder. 


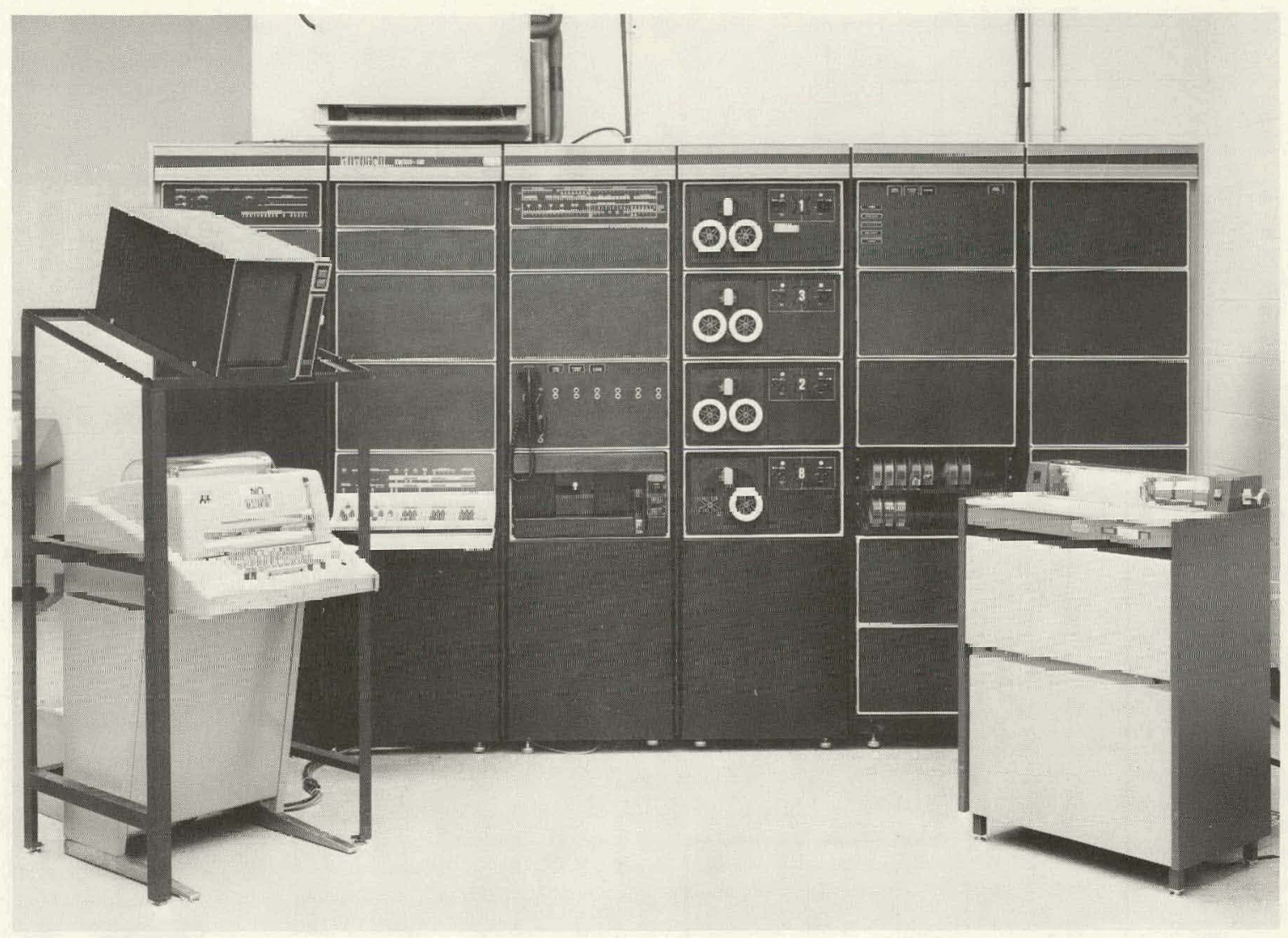

146923

Figure 3. MULTIUSER COMPUTER SYSTEM.

Beam Current Control - With all other parameters constant, the beam current is controlled by the grid bias. The grid bias is controlled by positioning the coarse bias switch and vernier bias potentiometer with stepping motors. Absolute encoders are attached to the motors, and digital displays indicate their positions. Switches are provided for positioning these motors in the manual mode.

The grid bias, as previously mentioned, is not the only parameter affecting the beam current. It would be difficult to store calibration data relating beam current to the positions of the grid bias control motors, and closed-loop control of the beam current was not feasible at this time. Therefore, a setup procedure designated as the "setup" mode is required to determine the required positions for the bias motors for a particular set of weld parameters. In the automatic mode during setup, the operator requests control data by Teletype for a particular set of weld parameters of the weld program. Then the operator positions the bias motors using the manual control switches until he obtains the desired beam current. $\mathrm{He}$ acknowledges satisfactory setting by Teletype, and the existing encoder positions are stored by the computer for use in the "auto weld" mode. This procedure is followed for each parameter set of a weld program.

In the automatic mode during an auto weld, the fine bias motor is driven to the commanded position contained in the appropriate active register at a fixed rate determined by a clock. 


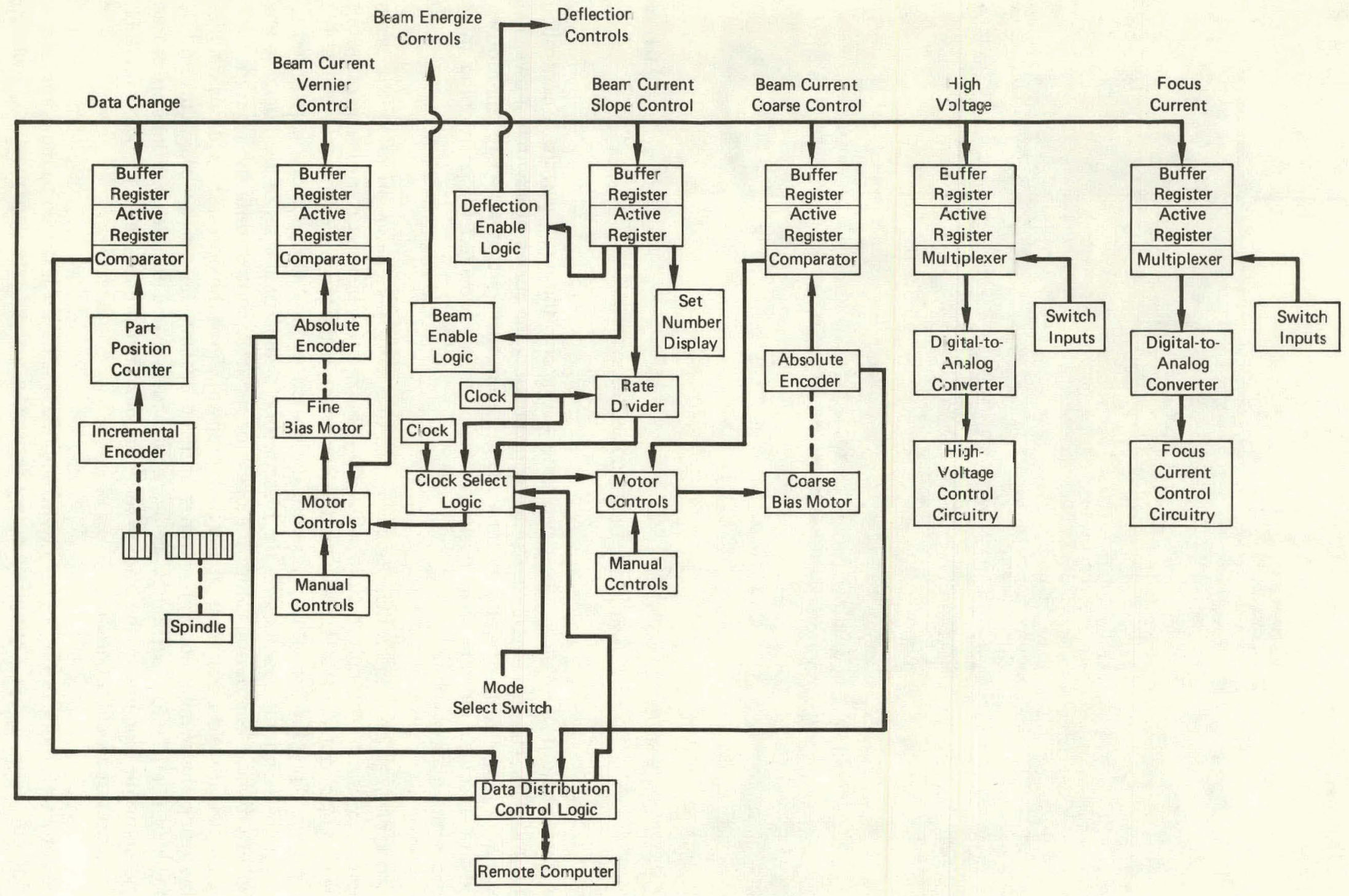

Figure 4. COMPONENTS OF THE PROGRAMMABLE CONTRCL CONSOLE. 
The coarse-bias motor is driven to the location stored in its active register at a rate programmed into an active register which controls a frequency divider. In each instance the desired position is compared to that of the absolute encoder until an equality occurs.

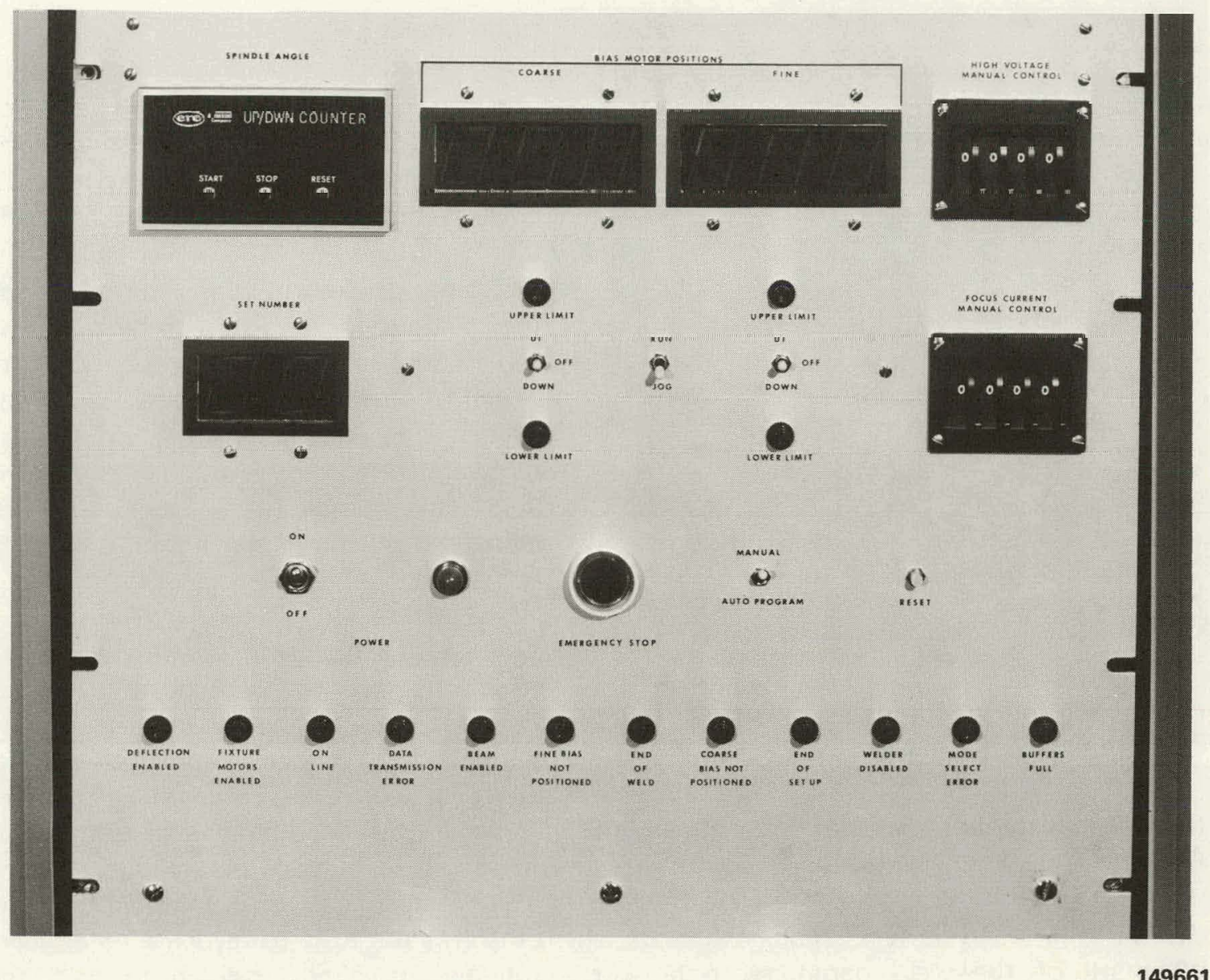

Figure 5. PROGRAMMABLE CONSOLE CONTROL PANEL.

Beam Current Enable and Beam Deflection Enable Logic - The beam current enable logic enables the beam-enable foot switch in the manual mode or in the automatic mode during setup or welding. The beam-deflection controls on the welder are similarly enabled by the beam-deflection enable logic.

Auto Weld Data Change Control - The programmed data change point corresponds to a part position where new parameter control data are needed during an auto weld. An incremental encoder is attached through a gear train to the rotary fixture holding the workpiece (see Figure 6 ). This encoder provides 3,600 pulses per revolution of the workpiece. These pulses are counted by a bidirectional counter. In the automatic mode during an auto weld, the cumulative part position is compared to the current data change point stored in an active register. A comparison causes new data to be transferred from the buffer registers to the active registers and generates a request for more data for the buffer registers. This process is repeated until the weld program is finished. A typical multipass weld program listing is given 


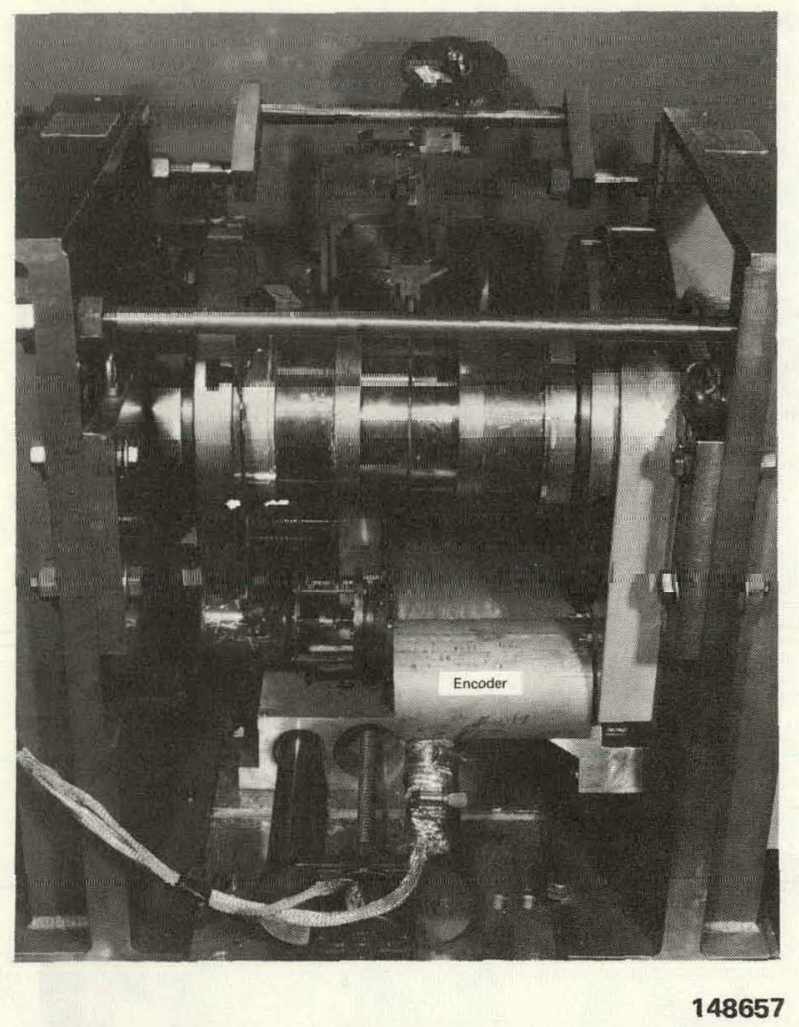

Figure 6. ROTARY FIXTURING, SHOWING THE PART POSITION ENCODER. in Figure 7. This program causes weld parameters to change, as indicated in Figure 8.

\section{Computer Interface}

The computer interface, outlined in hlor:k form in Figure 9, is the device through which all dald, cummands, and flays must pass. $\wedge$ bidirectional data link connects the interface to the PCC with the direction of transmission controlled by the computer. Special high quinlity dntn cable connects the adjacent buildings which house the computer and the welder, and current sensitive drivers and receivers are employed at each end of the link. This combination insures that the data link will be highly immune to noise and any degradation of signal.

The welder operator communicates instructions to the computer via the Teletype, and the computer responds by sending the proper commands to the interface which, in turn, relays them to the PCC. In the auto weld or setup mode, the PCC generates a load-buffers request flag to the interface whenever data are required. Data in the form of weld parameters are now loaded, one word at a time, into Data Register A which immediately places the word on the data link. A "load-buffers" request follows which informs the PCC to read the data word. When all of the weld parameter data words tor one weld pass have been sent, the load-buffers request changes state to indicate the receipt of a complete pass of data words. When the data for the next pass are required, the load-buffers request is again sent to the interface by the PCC and the process is repeated. An error detection circuit insures that the correct number of words is received by the PCC.

If a weld setup is to be performed, bias encoder position data must be received from the PCC after the other weld parameters for each pass are sent to the PCC. The coarse position is read first via the bidirectional data link and the "encoder data received" command is sent to the PCC which causes the PCC to place the fine encoder position on the data link. The fine encoder position is read, and the data link is reset for computer transmission of the next requested parameter set. This sequence is continued until the weld setup is completed.

\section{Computer Software}

The purpose of the computer software is to receive and store weld description files, to provide editing of stored files, to perform computer-assisted calibration and setup, and to feed back a file in the automatic weld mode. A weld description file consists of a table of 
weld-parameter set points and switching instructions for the PCC. In the auto weld mode, for example, the controller sequences through a weld procedure automatically, obtaining parameter sets as needed from the computer on an interrupt basis.

The computer software must run in a multiprogramming environment. The welder project is only one of several jobs on the medium-sized, multiuser computer. Only $4 K$ words of active core are allotted to the welder. Tho woldor program is much larger than $4 \mathrm{~K}$; and, so; is kept on the disc in a highly chained and overlayed form. The weld description files are kept on magnetic tape. The welder operator communicates with the computer program through a Teletype at the remote station.

Functions of the Computer Program - Figure 10 shows the general layout and function of the welder program. There are four major modes of operation: calibrate, files, setup, and auto weld, as indicated by the four major blocks. The calibrate mode allows the welder operator to input tables of digital control versus high voltage and digital control versus focus current to be used for converting high voltage and focus current entries in the weld description files into a digital form recognizable by the PCC. The calibration tables are interpolated by means of second-order polynomials fitted through the three table values nearest the point of interest.

Files mode is used for all operations on stored files. Specifically, new files may be created, and any weld file may be listed, edited, or deleted. A special provision allows for searching through the file headers (which contain identification and other descriptive material), so that a particular file may be found easily if its identification is not known, or if certain file characteristics are being sought. An example would be if the welder operator wanted to create a new file by editing some existing file and saving it under a new identifier. The original file is unchanged in such a case.

The Edit subprogram is a single-pass line editor written in Fortran language and capable of running in a $4 \mathrm{~K}$ partition of core. It works from a source file on magnetic tape into a scratch file on a disc and then back to tape with the edited file. The first five characters of a line are used as line identifiers. Editing commands are available for locating a particular line, for 


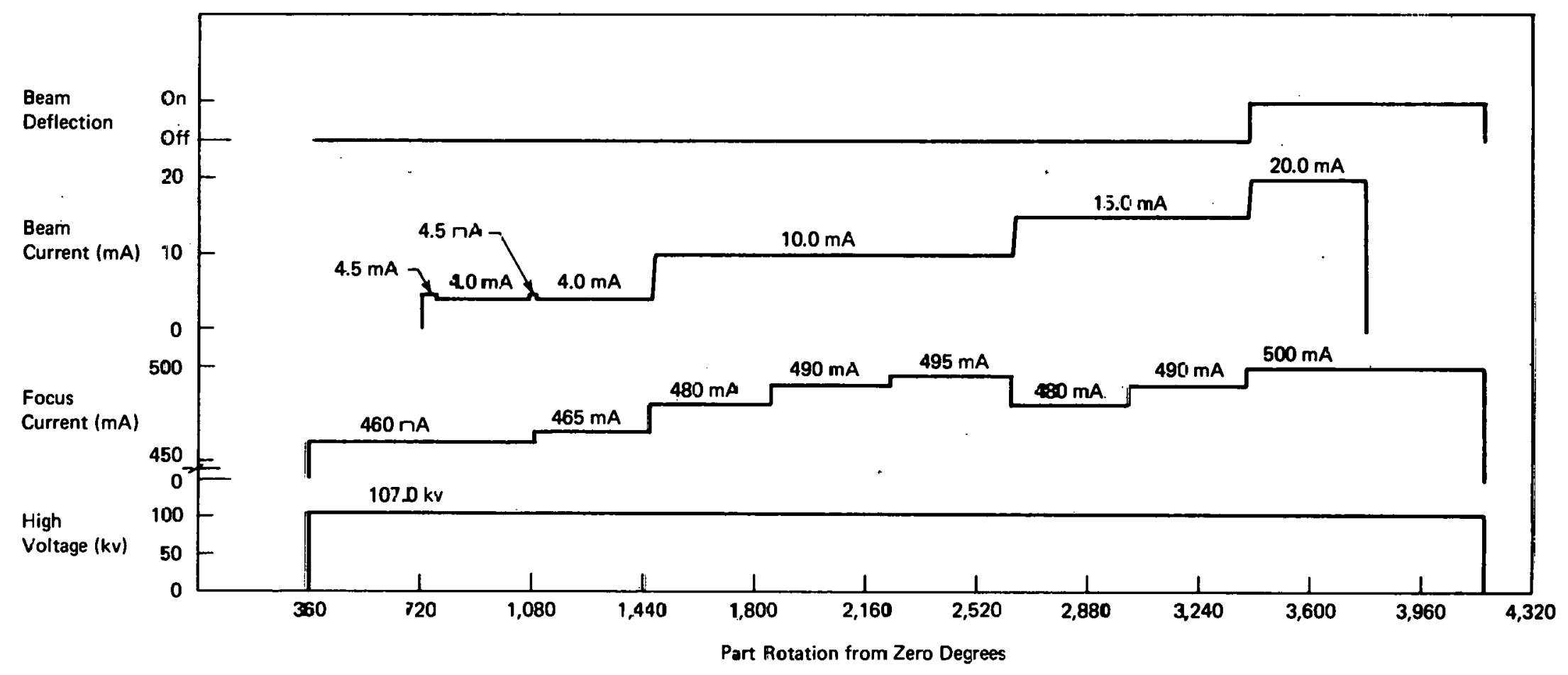

Figure 8. WELG PARAMETER CHANGES For the MULTIPASS WELD DESCRIBED BY FIGURE 7. 


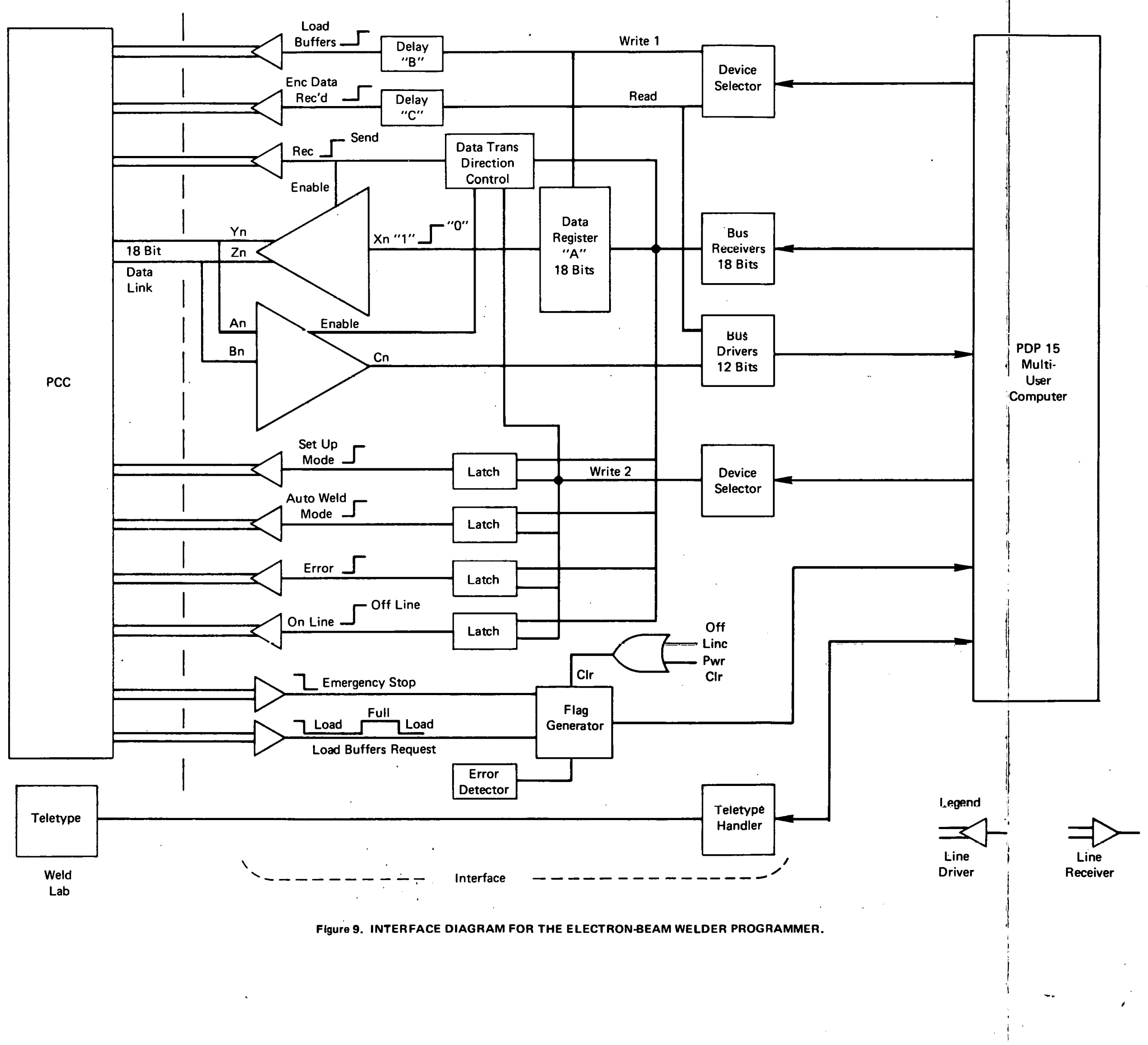




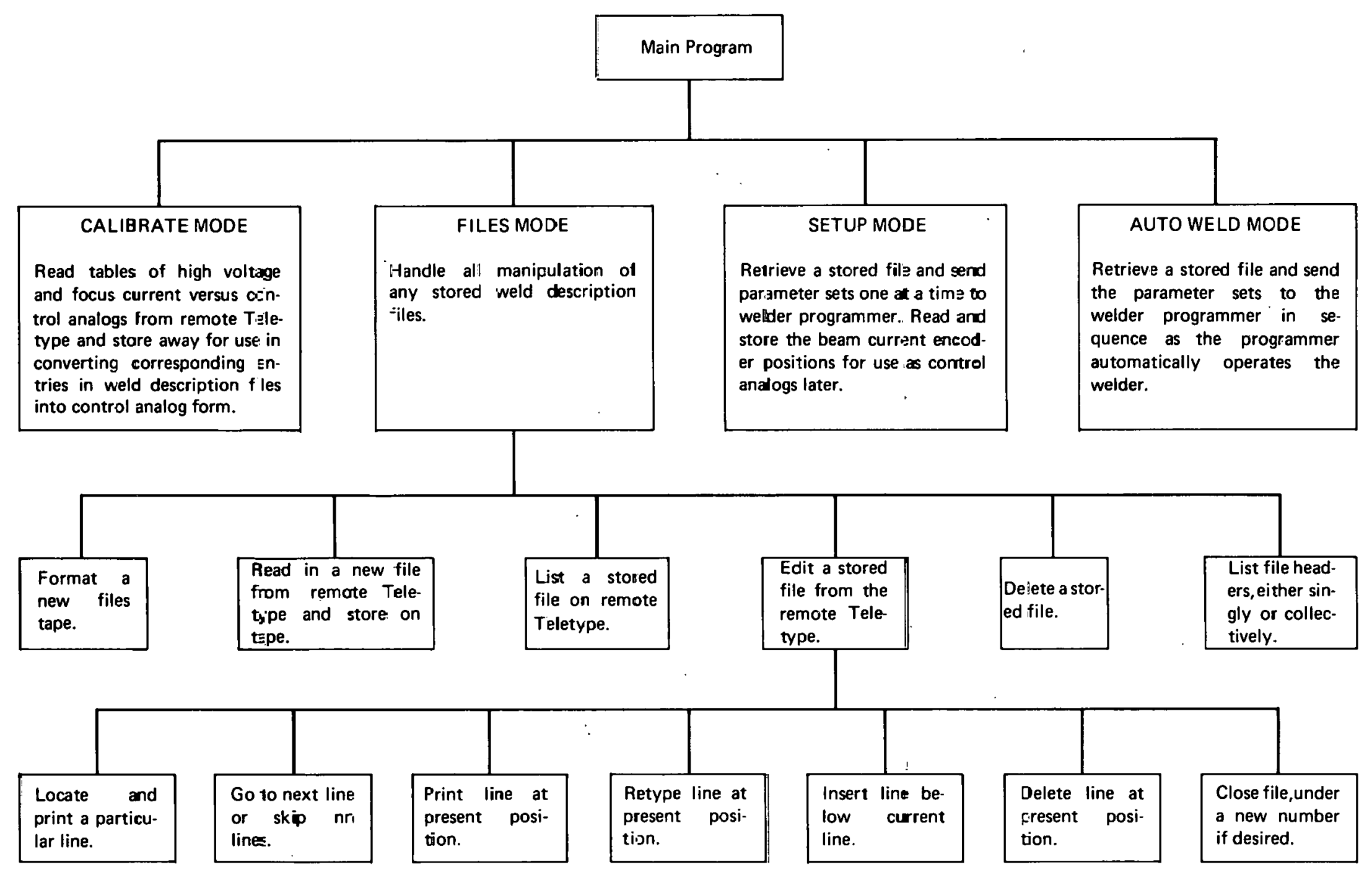

Figure 10. ELECTRON-BEAM WELDER COMPUTER PROGRAM F JNCTIJNS. 
moving down a specified number of lines, printing a line, retyping a line, inserting a line, deleting a line, and for closing the file under a specified identifier.

The setup mode allows the welder operator to experimentally obtain and store the correct beam current settings, given the high voltage and focus current settings. A test block is used for this purpose. When the welder operator creates a new file, he makes entries under the heading Beam Current. These entries are used for informational purposes only when the file is listed out. What is stored and sent to the PCC is a set of bias encoder positions which are read and stored in the setup mode.

In the auto weld mode, the computer sends the parameter sets to the PCC in the order in which they fall in the weld description file, on an interrupt basis. Response time is not critical hecause one extra set is buffered in ahead of time at the PCC. The computer specifically does not do any closed-loop control.

Operation of the Computer Program - The welder operator controls the functioning of the computer program by means of one and two-letter commands entered at the remote Teletype. Figure 11 shows the hierarchy of commands. I he program aiways returns to a decision point after completing any allowable task. The remote interface includes a direct-line intercom to the computer room. The welder operator must call to request service, and the computer operator mounts the files tape and starts the program. All the welder interrupts are blocked out of the computer by an online/offline arrangement controlled solely by the welder program. That is, the program itself turns the interrupts online and offline only when needed and expected, and the welder operator maintains control only indirectly through the program command hierarchy. Figures 12 through 16 are examples of the Teletype interaction required to perform typical operations using the computer. 


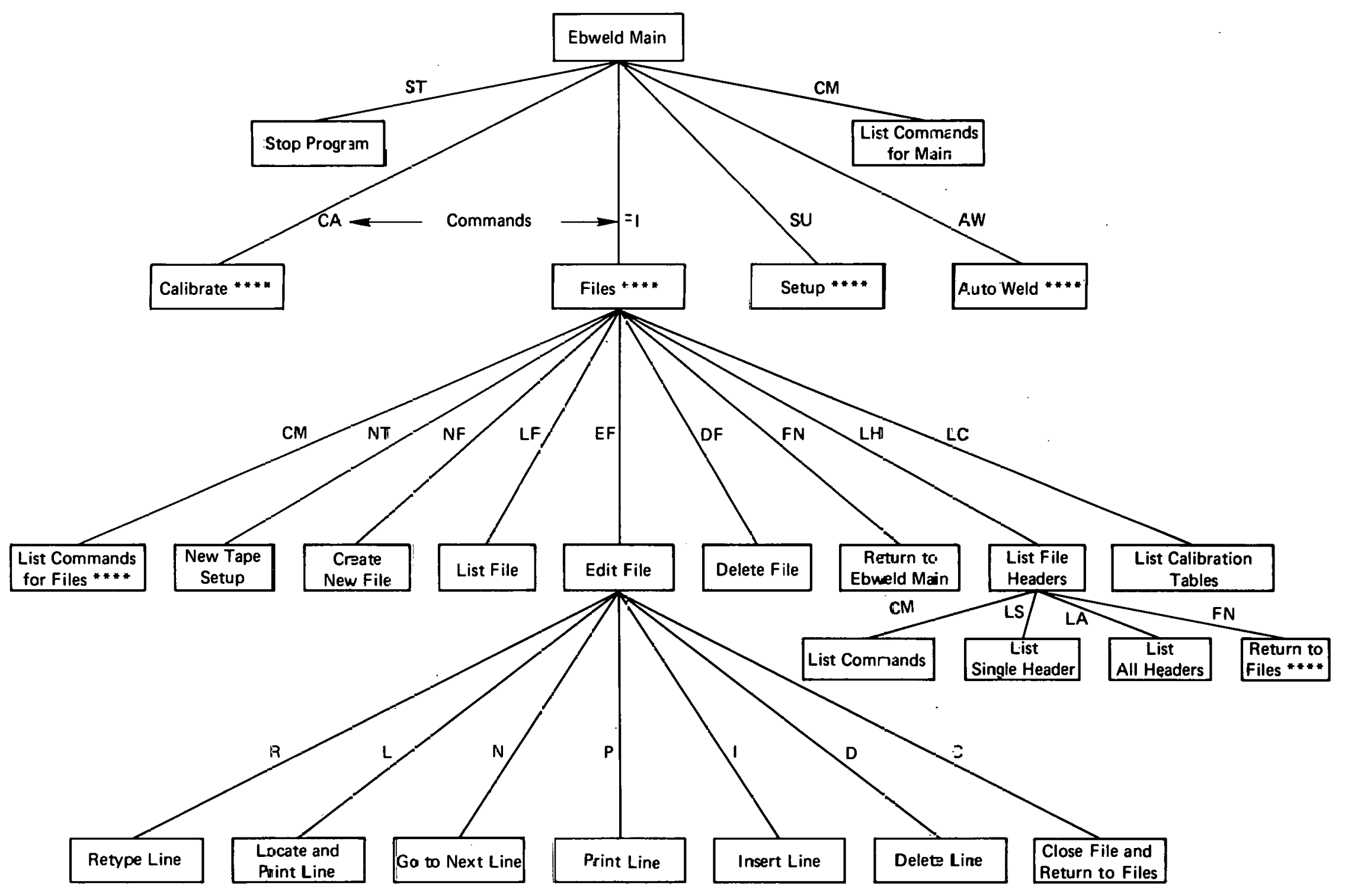

Figure 11. ELECTRON-BEAM WE LDER COMPUTER PROGRAM CCMMANDS. 


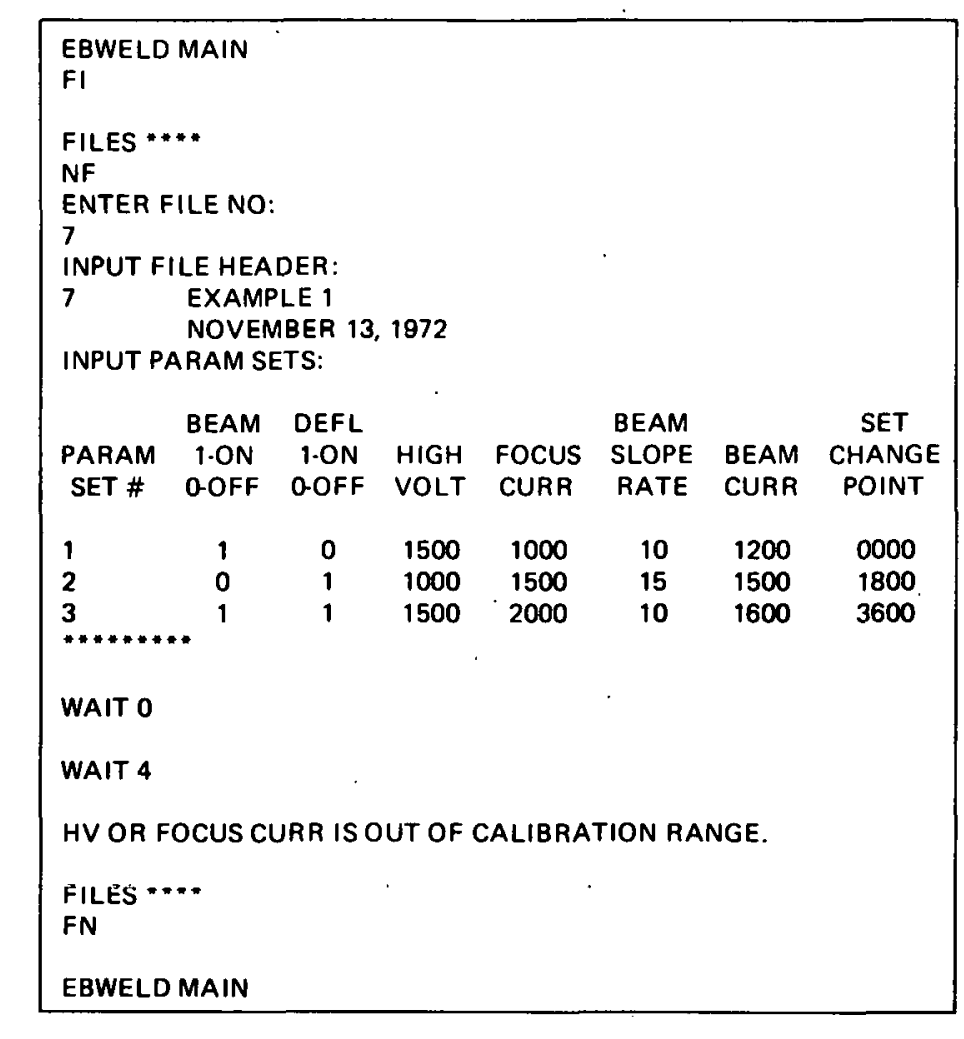

Figure 12. LISTING SHOWING THE PROCEDURE USED TO
R.REATE A NEW FLLE.

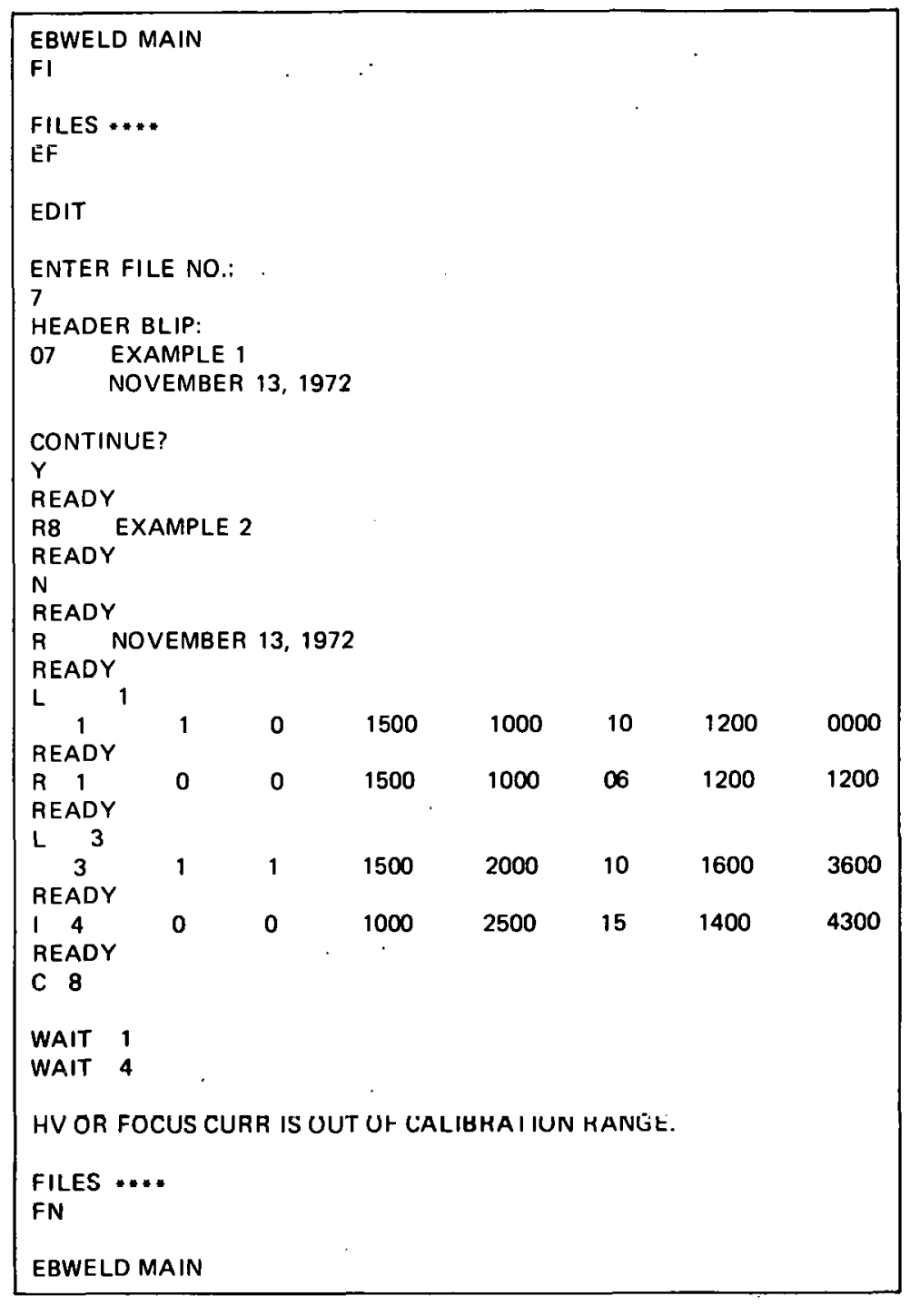

Figure 13. LISTING SHOWING TYPICAL FILE EDITING.

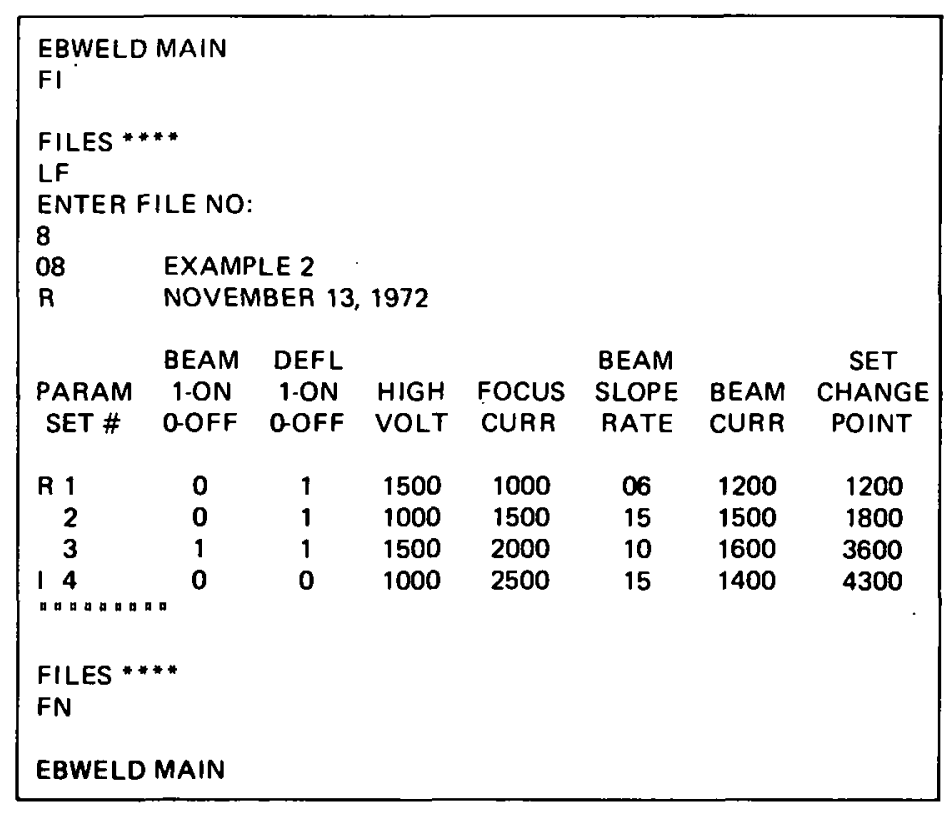

Figure 14. LISTING OF THE FILE AS EDITED IN FIGURE 13.

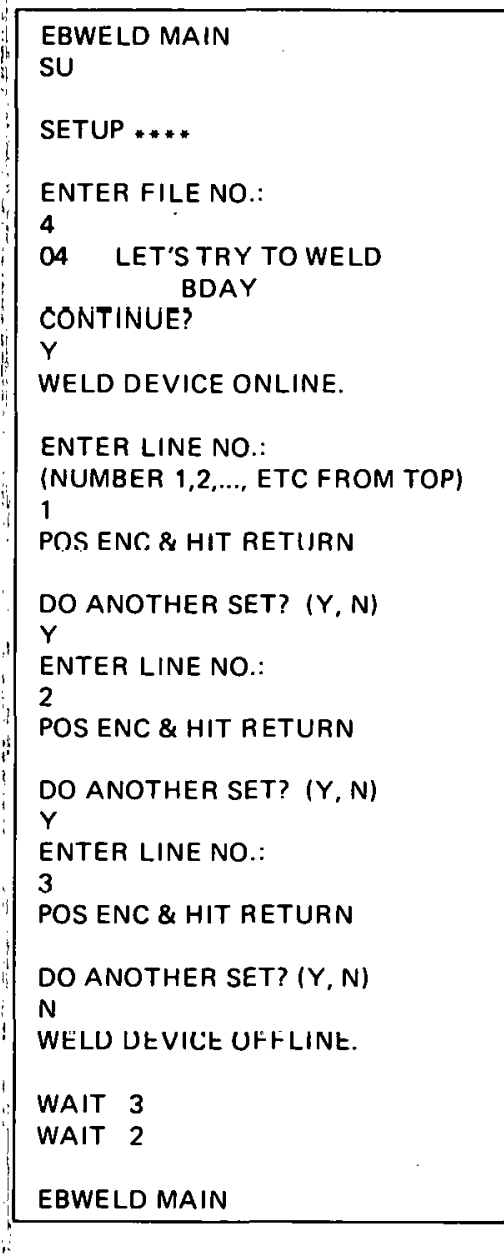

Figure 15. LISTING OF TELETYPE
RESPONSE DURING A SETUP.

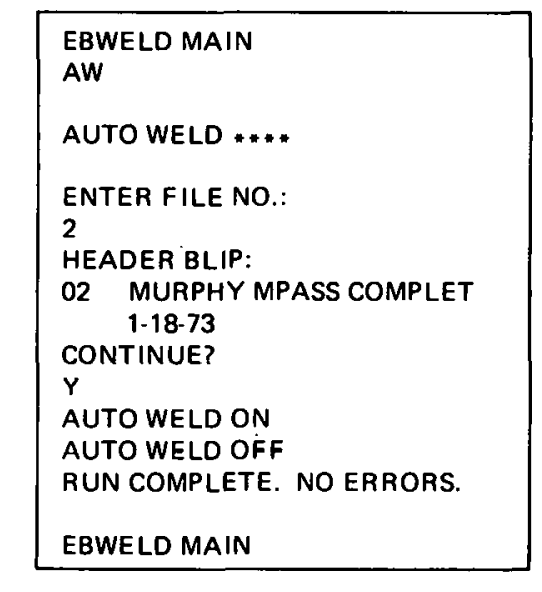

Figurr 16. AUTO WELD TELETYPE
RESPONSE. 


\section{DISTRIBUTION}

Atomic Energy Commission - ALO

Vespe, V. C.

Atomic Energy Commission - ORO

Hickman, H. D.

Zachry, D. S., Jr

Battclle Northwest

Lemon, L. C. (2)

Bendix - Kansas City

Bancroft, G. H. (2)

Dow - Rocky Flats

Kava, D.J.

Palan, R. C. (2)

DuFont, Gavannah River

Minton, H. C. (2)

General Electric - St. Petersburg

Rowe, W.

Strickley, W. H. (2)

Lawrence LIvermore Laboratory

Armstrong, R. E. (2)

Frazier, J. W:

McFarland, G. C.

Los Alamos Scientific Laboratory

Hanks, G. S. (2)

Mason and Hanger - Pantex

VanDoren, D. M. (2)
Monsanto - Mound Laboratories

Jones, W. H. (2)

Oak Ridge Gaseous Diffusion Plant

Barton, J. C.

McLaren, R. A.

Weber, C. W.

Wilcox, W. J., Jr

Winkel, R. A.

nak Ridge Nátional Laboratory

Adams, R. K.

Borkowski, C. J.

Oak Ridge Y-12 Plant

Alvey, H. E.

Bailey, H. L.

Bradburn, E. H.

Burditt, R. 8.

Burkhardt, J. H., Jr (15)

Burk.hart, L. E.

Butturini, W. G.

Davenport, C. M. (5)

Denny, A. (2)

Dodson, W. H.

Ellingson, R. D.

Fuulk, D. L.

Gray, D. H. (5)

Gritzner, V. B.

Hemphill, L. F.

Hensley, C. E.

Huber, R. A.

Johnson, L. D.

Jones, F. W.

Kahl, K. G.

Keith, Alvin

King, J. F.

Kite, H. T.

Lewis, T. J.

McMurray, C. S. 
Mitchel, G. W.

Murphy, J. L.

Oliphant, G. W.

Perry, A. E.

Preuss, H. M.

Scott, D. G.

Searcy, C. E.

Smith, H. F., Jr

Smith, R. D.

Speller, B. W.

Stephens, A. E.

Stoner, H. H.

Thompson, W. H., Jr

Tilsori, F. V.

Townsend, A. B.

Trotter, T. C.

Turner, P. W. (2)

Weathersby, W. E.

Wright, C. C.

Yaggi, W. J.

$Y-12$ Central Files (5)

$Y-12$ Central Files (master copy)

$Y-12$ Central Files (route)

Y-12 Central Files (Y-12RC)

Paducah Gaseous Diffusion Plant

Millican, $\mathrm{R}$.

Sandia - Albuquerque

Emerson, E. L.

Graham, J. H.

Watt, D. A. (2)

Sandia - Livermore

Library

Murphy, B. F.

In addition, this report is distributed in accordance with the category UC-38, Engineering and Equipment, as given in the USAEC Standard Distribution Lists for Unclassified Scientific and Technical Reports, TID-4500. 